\title{
Performance Analysis of Common Issues In the PV Transformer-Less Inverter Topology
}

\author{
N. H. Khan
}

\begin{abstract}
The Photovoltaic (PV) Panel is part and parcel in recent time where it has been used in the electricity generation through either in Transformer based or Transformer-less inverter topology. To reduce the limitation of using transformer based system, no transformer topology is highly popular where the main and common issue is leakage current through parasitic capacitance. In this paper, main focusing issue is leakage current hence, a new topology is introduced and for leakage current reduction purposes, Pulse Width Modulation (PWM) has used as a switching combination and compared with another topology.
\end{abstract}

Index Terms - Photovoltaic (PV), Pulse Width Modulation (PWM), Leakage Current, Parasitic Capacitor, Inverter.

\section{INTRODUCTION}

Electricity demand is escalating dramatically in different sectors especially the education, health, technology as well as welfare [1]. However, maximum lack of fulfilling areas is rural areas where they are facing in different issues such as health care, illiteracy rate, transportations and low electrification rate as well [2-4] where economical side is the vital one[5-7]. The source of electricity can be renewable or non renewable energy. At present, the renewable energy takes the leading position to produce electricity due to reduce the electrification problem in rural areas $[19,20]$. In 1660 to until now, there are few countries that are included under of OECD countries that already established the renewable energy in the rural sectors due to overcome the electrification problem. However, nowadays non OECD countries are also focused on Renewable Energy (RE) to find out the sustainable solution especially for the rural areas electrification problem. Hence, removing the electrification problem is becoming a big challenge[5, 12]in recent ages. For this issue, Government is also influencing the people to use RE technology to overcome the needs for rural electrification issue [13]. Before installing the power supply at remote areas, it is necessary to know the previous power installation system due to cost worries. [14-16]. RE demands are increasing day by day and because of two reasons that already discussed which are the electricity demands due to the increase of rural facilities as well as increasing of population and secondly the reduction of environmentally dangerous chemical emission for human which is $\mathrm{CO}$ [17]. As the energy demand is escalated

Manuscript published July 31, 2016

Md. Noman Habib Khan is a Lecturer in the Department of Electrical and Electronic Engineering (EEE), Uttara University (UU), Dhaka-1230, Bangladesh. (e-mail: nomanxp76.eee@uttaraUniversity.edu.bd). dramatically, the renewable energy especially solar takes the most important part where it's fully cost of free as well as environmental friendly [9]. Hence, the PV panels are commonly used nowadays in both cases stand alone and connected to grid as well where the core components are power conditioning and regulation make up. In the solar generation, inverters are used as a second core component where it may be used either in transformer-based or transformer-less system. However, in both cases, it does very good performance and expected outcome. Due to DC current management, PV panel works accurately when it converted to $\mathrm{AC}$ through inverter, although the main concentration is clean the environment as much as possible [21], [22]. Hence, transformer bears the most important part to handle the overall system. To achieve high range of power in the overall system, Grid connected inverter is highly popular through analog maximum or normal point tracking methods [23]. Throughout the researchers work transformer-less inverter system is being highly developed for getting high efficiency, less cost and size [20]. In contrast, galvanic isolation has been occurred in the PVTransformer-less inverter topology where the main problem is common mode leakage issue which is actually the reason of reducing the efficiency and increasing the loss [20], [24][25].

This paper is presented the working principle of Transformer-less inverter topology with importance respect of high efficiency achieving and the occurring common issues as well as solution process. At last will be proposed a PV-Transformer-less inverter where will be shown the wave shapes of Common Mode voltage and reduction of leakage current through Pulse Width Modulation (PWM).

\section{PV PANEL}

Solar panels are made of a thin layer of semi-conducting material between a sheet of glass and a polymer resin. When exposed to daylight, the semi-conducting material becomes 'energized' and this produces electricity. Solar panel systems are mainly two types one is solar water heating and another one is photovoltaic (PV) solar panels. A solar PV system is usually made of solar panels, an inverter, isolator switches, a PV generation meter and cables [26-27]. European and Australian householders are widely accepted by Government to use PV systems due to no rotary component, silence, roof installation as well as no pollution [28]. A PV cell is shown like in Fig. 1, where all bears their individual meaning like I is overall current, IPH is the photo-generated current, Rs is panel series resistance and Rsh is the panel parallel (shunt) resistance [29]. 


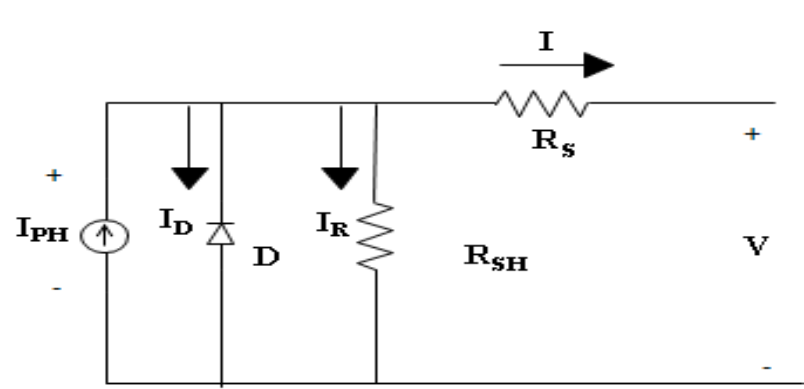

Fig. 1. Photovoltaic (PV) Cell equivalent circuit [29]

In photovoltaic (PV) panels the output depends on temperatures, load conditions as well as various irradiance which are very important for maximum power point tracking (MPPT) that can be found by I-V characteristics and V-P curves. Meanwhile, in above circuit diagram, maximum power depends on output achieving voltage and current where the output current is exponentially developed with junction thermal voltage $\mathrm{Vt}$, that shown through below equation.

$$
I=I P H-I 0\left(e^{\frac{V+I_{R}}{n_{s} V_{t}}}-1\right)-\frac{V+I_{R_{S}}}{R_{S H}} \text { and where } V_{t}=\frac{A K T_{s t c}}{q}
$$

Where $\mathrm{A}=$ diode quality factor (ideally), $\mathrm{K}=$ Boltzmann's constant, $\mathrm{q}=$ the charge of the electron, $\mathrm{ns}=$ the number of cells, $\mathrm{T}_{\mathrm{stc}}=$ standard test constant (stc) temperature in kelvin. Io= dark saturation current in STC. In Fig. 2 below is shown the $\mathrm{I}-\mathrm{V}$ and $\mathrm{P}-\mathrm{V}$ characteristics under given light irradiance level at which it gives Isc under shortcircuit condition while Voc is the output voltage when the panel is open. Maximum power at Pmax is indicated at current IMP, and voltage VMP respectively.

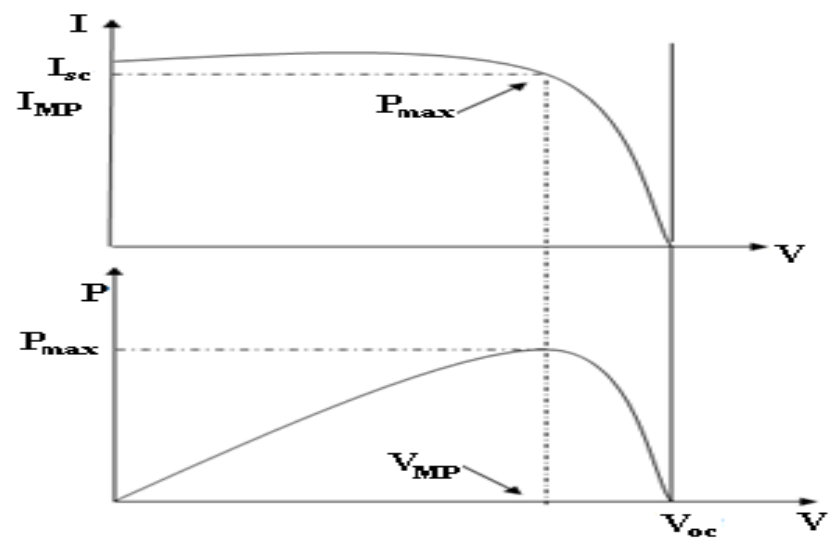

Fig. 2. I-V characteristics and P-V curve and maximum power achieving point [30].

The solar PV systems, the most important are size and types due to price consult as well as where it will be installed. Approximately costs will be $€ 5,000$ to $€ 8,000$ for $4 \mathrm{kWp}$ (kilowatt peak) PV system. In additionally, in this system initial cost is higher than overall processing cost. After generating the own electricity under the Feed-in Tariff (FIT), it's possible to savings on your bill. The idea behind the FIT is that as solar PV takes off, the cost will drop. And this is why the rate of the FIT is decreasing over time to compensate for the falling cost of solar systems. In below has been shown a graph where clearly shown the cost for solar PV from 2011 to 2015 [31].

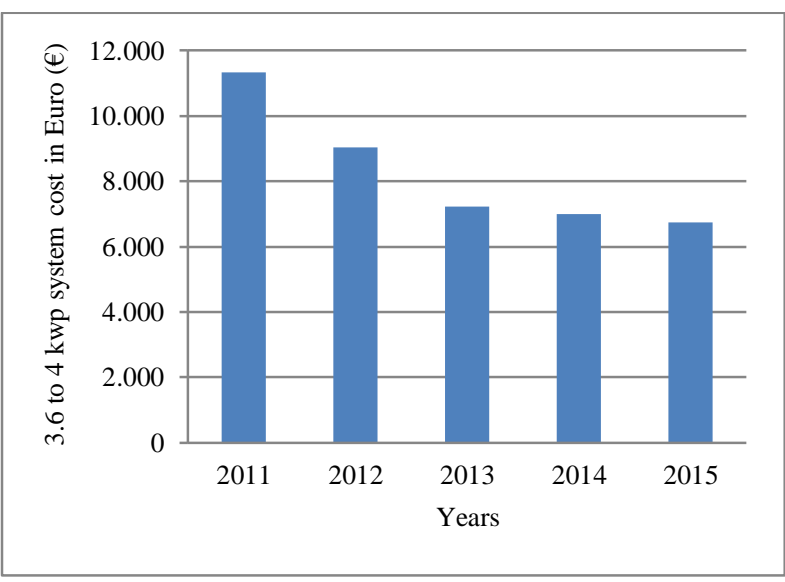

Fig. 3: 3.6 to 4 kwp PV system cost paid by members from 2011 to 2015

\section{TRANSFORMER-LESS INVERTER}

Transformer-less inverter basically have some common advantages whereas transformer does not have such as in reduced size, complexity, and weight along with improved efficiency. At present, it's become highly part and parcel to get more electricity with low cost [32]. No transformer system in the PV inverter which is reduced losses, costs, and size [18, 33-37]. To introduce the common issue which is occurred due to galvanic isolation of the electrical grid in the PV no Transformer inverter system. This common issue is leakage current that flows through the parasitic capacitance between the PV array and the ground. In additionally, the leakage currents increase conducted and radiated harmonics injected, electromagnetic emissions in the electrical grid, and losses [38-39]. Grid-connected of photovoltaic (PV)-Transformer less Inverter systems have developed rapidly and widely hence, reduce the PV-panel price [40].

\section{PROPOSED PV-TRANSFORMER-LESS INVERTER TOPOLOGY}

In this approach shown in Fig.4 is a transformer-less topology, which is actually made by using full bridge transformer-less inverter topology and de decoupling technique where uses extra one switch (S7). In total, in this proposed topology used seven switches where four switches are connected alternatively to make a inverting process smoothly. This idea actually achieved from full bridge technique and the proposed topology has been compared with H6 topology. Here used extra switch with filter to make a new transformer-less inverter topology. Meanwhile, in fig.4 shows the leakage current path which is through parasitic capacitor that automatically created in between PV panel to ground.

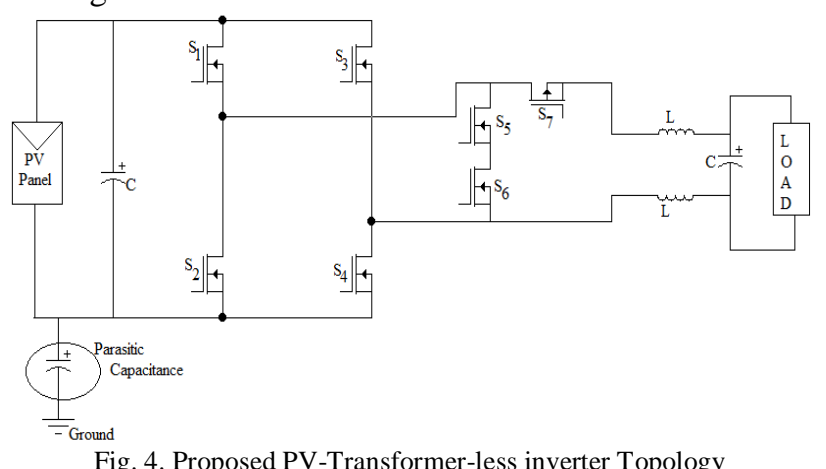




\section{REDUCED LEAKAGE CURRENT PROCESS}

\section{A. Switching Techniques for Leakage Current Reduction}

In Fig. 4 has been shown the proposed topology and it will be compared with $\mathrm{H} 6$ topology. In below mentioning table I and table II are the tables where show the values of leakage current and output voltages for both H6 and proposed technique.

Duty cycle, $\mathrm{D}=50 \%$ (switching on/off time is equal)
In the case of $50 \%$ duty cycle in table I when switch S1 and $\mathrm{S} 4$ is in on $\mathrm{S} 2$ and $\mathrm{S} 3$ is in off mode that works is in opposite direction and S5 and S6 is the DC decoupling switches and it connects alternatively to work accurately. After using the six switches in 50\% duty ratio, output voltage can be got around $10.5 \mathrm{~V}$, but the leakage current is occurred more that varies from -325.75fA to $-480.21 n \mathrm{~A}$. On the other hand, this leakage current is varies from $11.024 \mathrm{u}$ to $20.618 \mathrm{pA}$ for H6 transformer-less inverter topology and Here selected only one leakage path.

TABLE I: 50\% DUTY CYCLE OF INVERTER AND DIFFERENT SWITCHING CONDITIONS ARE USED FOR APPROACH TOPOLOGY

\begin{tabular}{|c|l|l|l|l|l|l|c|c|c|}
\hline S1 & S2 & S3 & S4 & S5 & S6 & S7 & $\begin{array}{c}\text { Vout } \\
\text { (V) } \\
\text { current PV-G (A) } \\
\text { (H6) } \\
\text { current PV-G (A) } \\
\text { (Proposed } \\
\text { Topology) }\end{array}$ \\
\hline ON & OFF & OFF & ON & OFF & ON & ON & 10.29 & $302.129 \mathrm{u}$ & $-480.21 \mathrm{n}$ \\
\hline OFF & ON & ON & OFF & OFF & ON & OFF & 10.40 & $50.367 \mathrm{u}$ & $360.997 \mathrm{p}$ \\
\hline ON & OFF & OFF & ON & OFF & ON & ON & 11.01 & $20.618 \mathrm{p}$ & $-819.45 \mathrm{n}$ \\
\hline OFF & ON & ON & OFF & ON & OFF & OFF & 10.89 & $11.024 \mathrm{u}$ & $-325.75 \mathrm{f}$ \\
\hline
\end{tabular}

Duty cycle, $\mathrm{D}=75 \%$ (switching off time is one fourth while on time is three quarter)

In the case of $75 \%$ duty cycle when leakage current has occurred through one path that has been shown in Table II for when switches $\mathrm{S} 1$ and $\mathrm{S} 4$ is in on mode than the switches $\mathrm{S} 2$ and $\mathrm{S} 3$ is in off mode that works is in opposite direction and S5 and S6 is the DC decoupling switches and it connects alternatively to work accurately that fixed in $75 \%$ duty ration and rest of the switch which is proposed switches are fixed in $50 \%$ duty cycle, output voltage can be got more than $11 \mathrm{~V}$ which is more that which is achieved for $50 \%$ duty ration but the leakage current is occurred which is reduced from the $50 \%$ duty ration that varies from $-325.7 \mathrm{n}$ to $-52.85 f$ Amp.

TABLE II: 75\% DUTY CYCLE OF INVERTER AND DIFFERENT SWITCHING CONDITIONS ARE USED FOR APPROACH TOPOLOGY

\begin{tabular}{|c|c|c|c|c|c|c|c|c|c|}
\hline S1 & S2 & $\mathrm{S} 3$ & $\mathrm{~S} 4$ & S5 & S6 & S7 & $\begin{array}{ll}\mathrm{V}^{\text {out }} & \end{array}$ & \begin{tabular}{l}
\multicolumn{2}{c}{ Leakage } \\
current PV-G \\
(A) \\
(H6)
\end{tabular} & $\begin{array}{l}\text { Leakage } \\
\text { current PV-G } \\
\text { (A) (Proposed } \\
\text { Topology) }\end{array}$ \\
\hline OFF & $\mathrm{ON}$ & $\mathrm{ON}$ & OFF & OFF & $\mathrm{ON}$ & $\mathrm{ON}$ & 11.09 & $192.129 n$ & $182.874 \mathrm{n}$ \\
\hline OFF & $\mathrm{ON}$ & $\mathrm{ON}$ & OFF & OFF & $\mathrm{ON}$ & OFF & 11.04 & $502.387 \mathrm{u}$ & $23.987 p$ \\
\hline OFF & $\mathrm{ON}$ & $\mathrm{ON}$ & OFF & $\mathrm{OFF}$ & ON & $\mathrm{ON}$ & 10.86 & $-20.618 n$ & $-325.7 n$ \\
\hline $\mathrm{ON}$ & OFF & OFF & $\mathrm{ON}$ & $\mathrm{ON}$ & OFF & OFF & 10.95 & $110.034 \mathrm{p}$ & $-52.85 f$ \\
\hline
\end{tabular}

B. Wave Shapes of Reducing Leakage Current by Load Effect

The Leakage current (LC) has occurred in different places and in this paper has been considered only two paths. It has been simulated through PSpice software after constricting the circuit together. The value of leakage current for PV panel to ground is changed from when we consider in one path that has been shown in above in a tabular form. Below is shown the considering paths where leakage current is occurred.

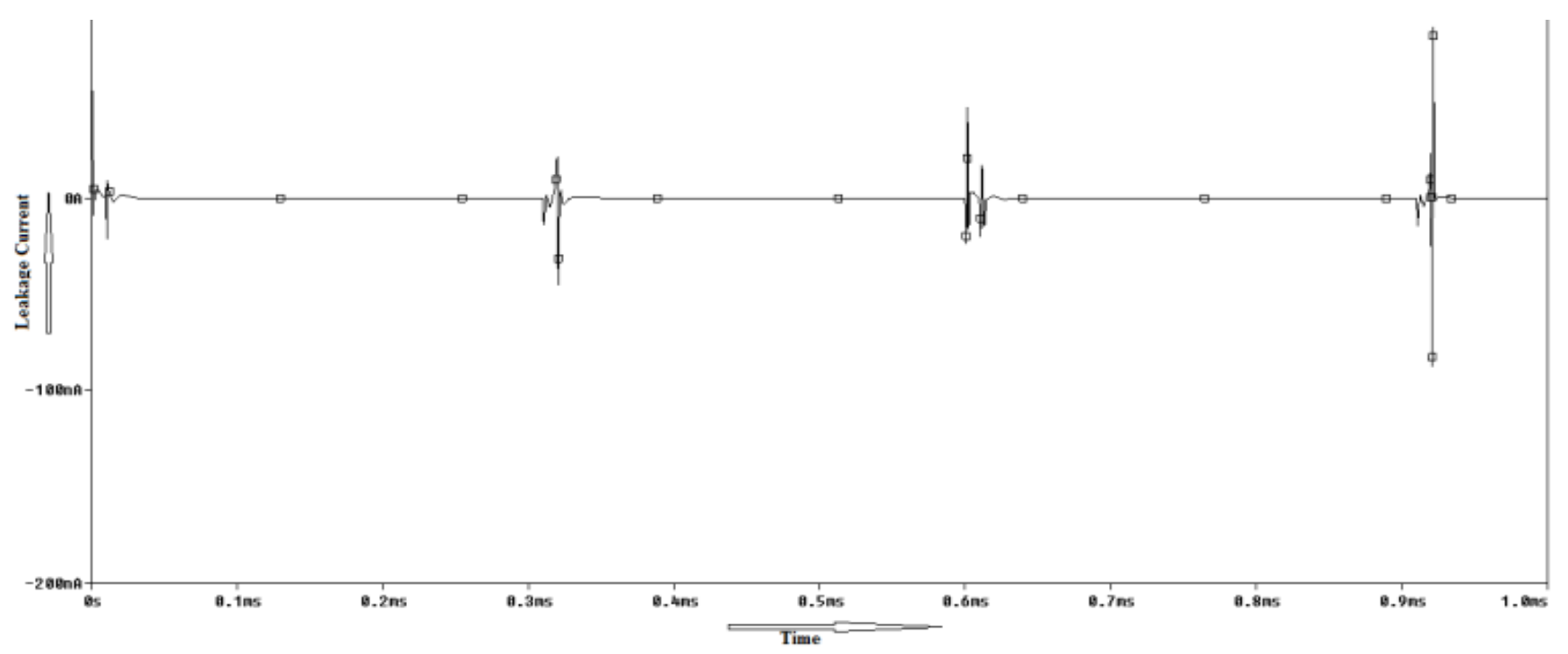

Fig.5. Leakage Current through PV panel to Ground through parasitic Capacitance (10 $\Omega$ ) 
One path is in between PV Panel to ground and another one is in between two sides of PV panel.
In the Fig.5 shows the leakage current when the considering load is very low with $10 \Omega$ and the leakage current is occurred low amount in the switching on/off time.

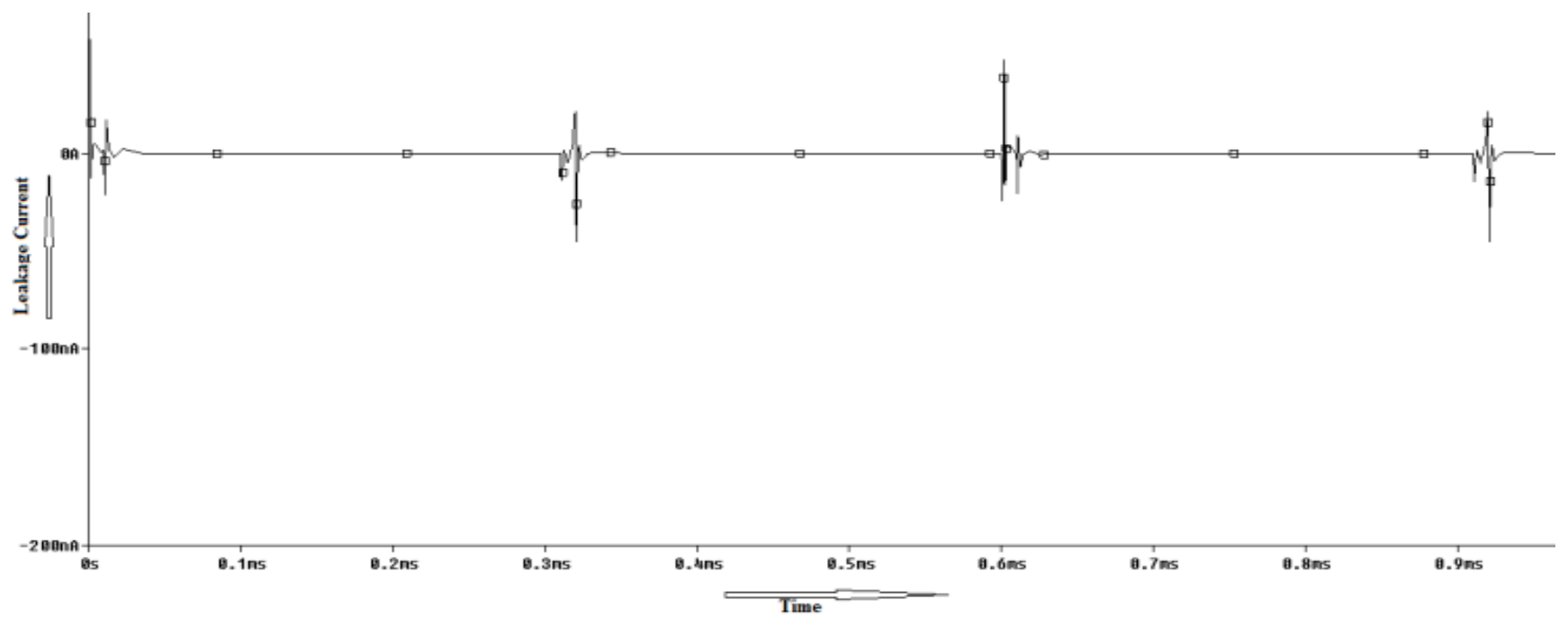

Fig.6. Leakage Current through PV panel to Ground through parasitic Capacitance $(1 \mathrm{~K} \Omega)$

Rest of the time it shows comparatively very low. On the other hand, Fig.6 and Fig.7 show the leakage current after changing the load to kilo and mega range.

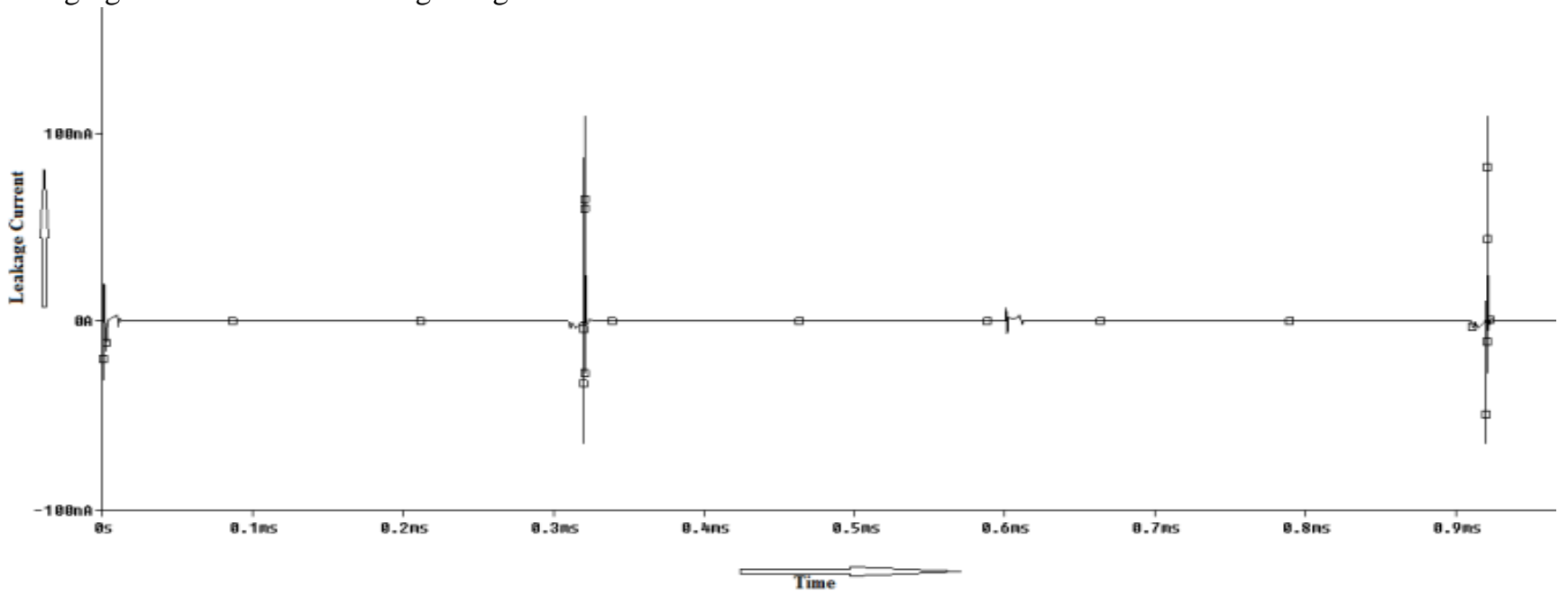

Fig.7. Leakage Current through PV panel to Ground through parasitic Capacitance (1 meg $\Omega$ )

When the effect is very clear and occurring leakage current is gradually increased respectively 


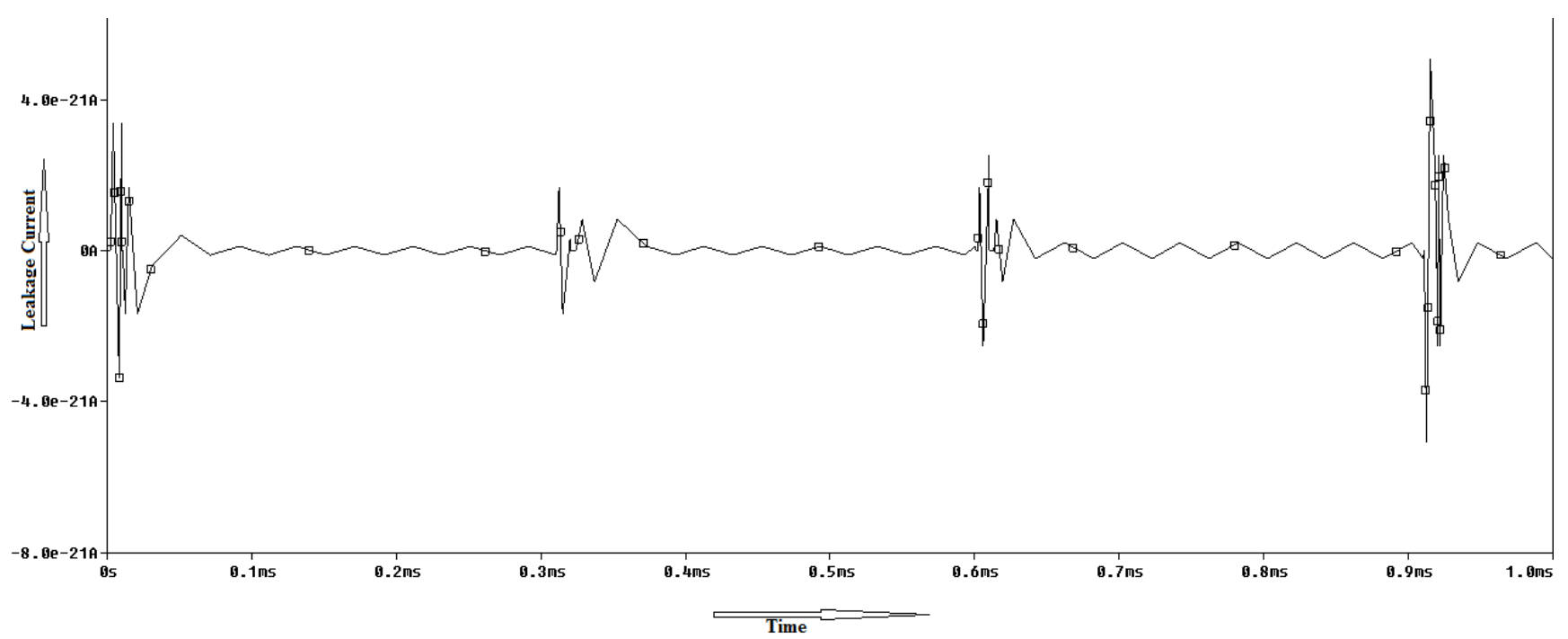

Fig.8. Leakage Current in between two sides of PV panel (10 $\Omega)$

Another considering path is mentioned before which is PV panel side where the leakage current is occurred very low amount.

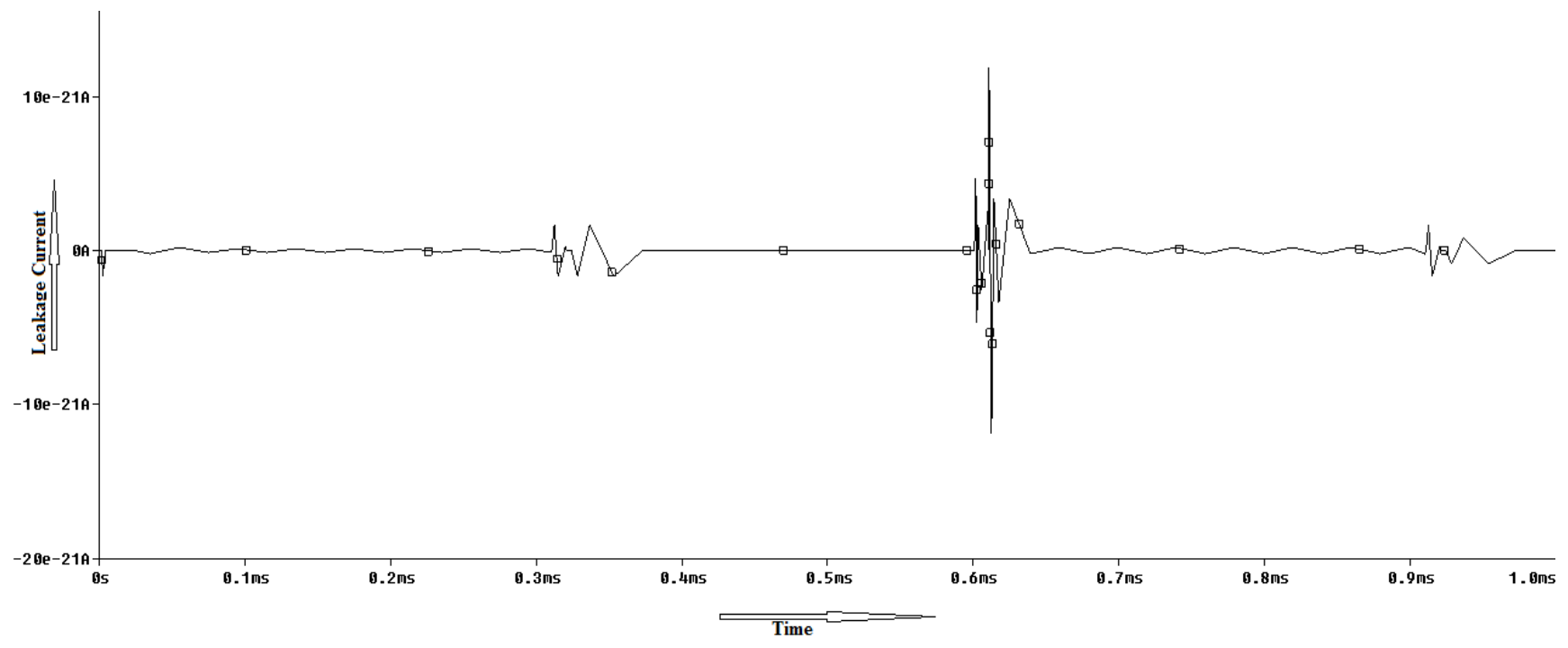

Fig.9. Leakage Current in between two sides of PV panel $(1 \mathrm{~K} \Omega)$

Here showed that the leakage current is flowing not only in the switching on/off time but whole time too. However, in the switching on/off time, it affected more.

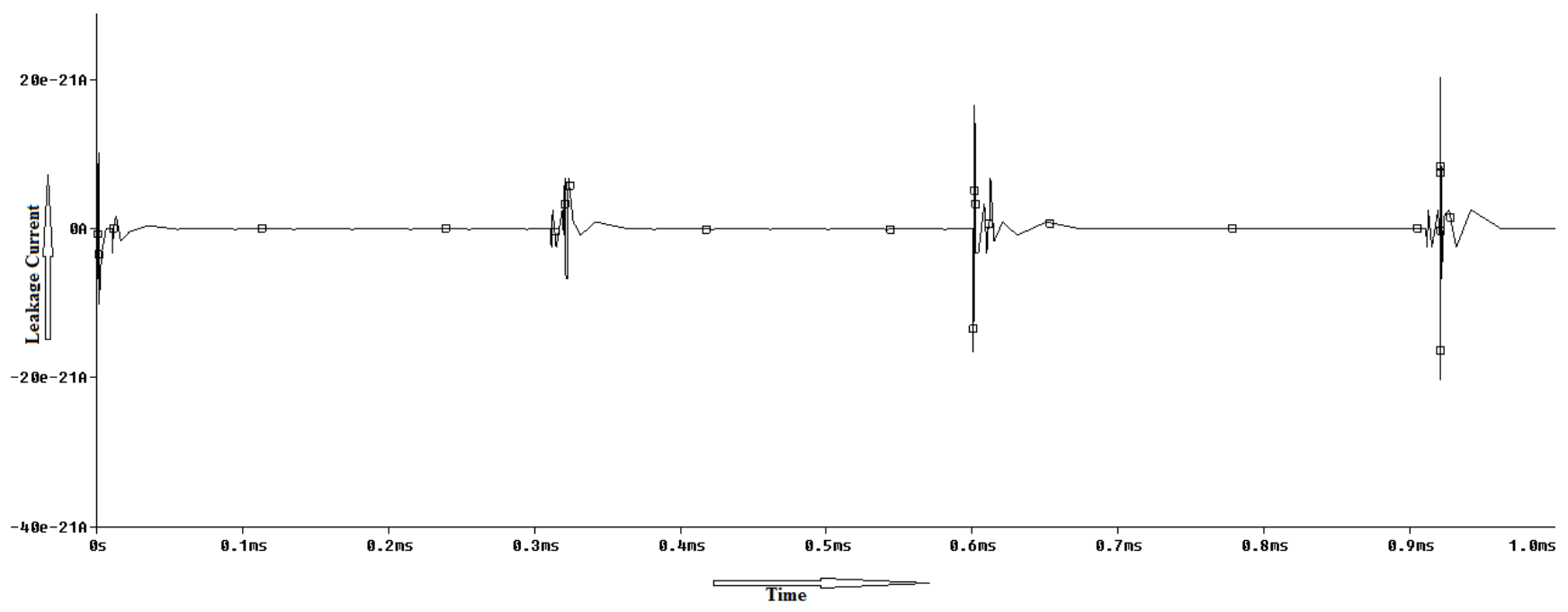


Fig.10. Leakage Current in between two sides of PV panel (1meg $\Omega$ )

In the road effect, it works oppositely. When the load is $10 \Omega$, the leakage current is more occurred compared to increasing the load to kilo and mega range.

\section{CONCLUSION}

Leakage current due to galvanic isolation is the main limitation of PV transformer-less inverter topology. To reduce the leakage current Pulse Width Modulation (PWM) brings the vital role. In this paper shows two leakage current paths and considering $50 \%$ and $75 \%$ duty cycle for reducing leakage current. Here shows the leakage current reduction in tabular form which has compared with another topology. Furthermore shows the effect of different load in the system for reducing the leakage current.

\section{REFERENCES}

[1] F.S. Javadia, B.R., M. Sarrafa, O. Afshara, R. Saidura, H.W. Pinga, N.A. Rahim, Global policy of rural electrification. Renewable and Sustainable Energy Reviews, Vol. 19, pp. 402-416, 2013.

[2] Cook, P., Infrastructure, rural electrification and development. Energy for Sustainable Development, Vol.15, No.3, pp. 304-313, September 2011.

[3] Sabah Abdullaha, A.M., Rural electrification programmes in Kenya: Policy conclusions from a valuation study. Energy for Sustainable Development, Vol.16, No.1,pp. 103-110, 2012.

[4] A.A. Lahimer, M.A.A., , Fadhil Yousif, T.M. Razykov, N. Amin, K. Sopian, Research and development aspects on decentralized electrification options for rural household. Renewable and Sustainable Energy Reviews, Vol.24, pp. 314-324, August 2013.

[5] Tobias S. Schmidt, N.U.B., Ratri Sryantoro Wakeling, Attracting private investments into rural electrification-A case study on renewableenergy based village grids in Indonesia. Energy for Sustainable Development, Vol.17, No.6, pp. 581-595, 2013.

[6] W.T. Chong, M.S.N., S.C. Poh, T.M.I. Mahlia, K.C. Pan, Technoeconomic analysis of a wind-solar hybrid renewable energy system with rainwater collection feature for urban high-rise application. Applied Energy, Vol.88, No.11, pp. 4067-4077, November 2011.

[7] Kusakana, K., A survey of innovative technologies increasing the viability of micro-hydropower as a cost effective rural electrification option in South Africa. Renewable and Sustainable Energy Reviews, Vol.37, pp. 370-379. 2014.

[8] Mignon I, Bergek A. "Investments in renewable electricity production: The importance of policy revisited". Renewable Energy. Vol.88, pp.307-316, April 2016.

[9] Khan MN, Ahmad KJ, Khan S, Hasanuzzaman M. "Leakage Current Paths in PV Transformer-Less Single-Phase Inverter Topology and Its Mitigation through PWM for Switching." International Journal of Power Electronics and Drive Systems. Vol. 6, No.1, pp.148-159, March 2015.

[10] Victor M. Sanchez, A.U.C.-R., Sergio M. Duron-Torres, J. Hernandez, L.G. Arriaga, Juan M. Ramirez, Techno-economical optimization based on swarm intelligence algorithm for a stand-alone wind-photovoltaic-hydrogen power systemat south-east region of Mexico. ScienceDirect, Vol.39, No.29, p. 16646-16655., 2014.

[11] Hussein A. Kazem, T.K., K. Sopian, Sizing of a standalone photovoltaic/battery system at minimum cost for remote housing electrification in Sohar, Oman. Energy and Buildings, Vol.61, pp. 108-115, 2013

[12] Tamer Khatib, K.S., Azah Mohameda, Mohd Zamri Ibrahim, Sizing of a wind charger at minimum cost for remote housing electrification: A case study for nine coastal sites in Malaysia. Energy and Buildings, Vol. 51, pp. 185-190, 2012.

[13] Tamer Khatiba, A.M., K. Sopian, A review of photovoltaic systems size optimization techniques. Renewable and Sustainable Energy Reviews, Vol.22, pp. 454-465, 2013.

[14] Patrícia Carneiro, P.F., The economic, environmental and strategic value of biomass. Renewable Energy, Vol.44, pp. 17-22, 2012.
[15] Akanksha Chaureya, T.C.K., Assessment and evaluation of PV based decentralized rural electrification: An overview. Renewable and Sustainable Energy Reviews, Vol.14, No.8, pp. 2266-2278, 2010.

[16] Sadhan Mahapatra, H.N.C., S. Dasappa, Evaluation of various energy devices for domestic lighting in India: Technology, economics and $\mathrm{CO} 2$ emissions. Evaluation of various energy devices for domestic lighting in India:Technology, economics and CO2emissions, Vol.13, No.4, pp. 271-279, 2009.

[17] Samba Sowe, N.K., Prapita Thanarak, Tawat Suriwong, Technical and Economic Viability Assessment of PV Power Plants for Rural Electrification in the Gambia. ScienceDirect,2013International Conference on Alternative Energy in Developing Countries and Emerging Economies, Vol.52, pp. 389 - 398, 2014.

[18] Khan Md, et al. DC-AC inverter with perspective of common mode and wave-shaping. IEEE International Conference on Smart Instrumentation, Measurement and Applications (ICSIMA), pp.1-5, 2013.

[19] Koumi Ngoh Simon et al. Comparison of Predictive Models for Photovoltaic Module Performance under Tropical Climate. TELKOMNIKA, Vol.10, No.2, pp.245 256, 2012.

[20] Karthick SP, et al. Modelling of Single Stage Inverter for PV System Using Optimization Algorithm. TELKOMNIKA Indonesian Journal of Electrical Engineering, Vol.12, No.9, pp. 6579-6586, 2014

[21] Khan Md, et al. Wave shaping with reduced leakage current in transformer-less inverter. IEEE International Conference on Smart Instrumentation, Measurement and Applications (ICSIMA), pp.1-5, 2013.

[22] Kerekes, et al. Transformerless photovoltaic inverters connected to the grid. Proceedings of the APEC, pp.1333-1337, 2007.

[23] Yang, Chih-Yu, et al. Highly efficient analog maximum power point tracking (AMPPT) in a photovoltaic system. IEEE Transactions on Circuits and Systems I: Regular Papers,Vol.59, No.7, pp.1546-1556, 2012.

[24] Gu, Yunjie, et al. Transformerless inverter with virtual DC bus concept for cost-effective grid-connected PV power systems. IEEE Transactions on Power Electronics, Vol.28, No.2, pp.793-805, 2013.

[25] Barater, Davide, et al. Unipolar PWM strategy for transformerless PV grid-connected converters. IEEE Transactions on Energy Conversion, Vol.27, No.4, pp.835-843, 2012.

[26] What are solar panel? http://www.which.co.uk/. Cited 21/06/2016.

[27] How does solar PV work?. http://www.which.co.uk/. Cited $21 / 06 / 2016$

[28] Ma, Lin, et al. "Leakage current analysis of single-phase transformerless grid-connected PV inverters." 41st Annual Conference of the IEEE on Industrial Electronics Society, 2015

[29] D. Sera, Teodorescu, R., \& Rodriguez, P. , PV panel model based on datasheet values, IEEE International Symposium on In Industrial Electronics, pp. 2392-2396, , June 2007.

[30] E. Setiawan., P-V and I-V curve. ,http://hijwho.sakura.ne.jp/labwp/?page_id=48, February 222012 , Cited at 28/02/2016.

[31] Solar PV prices and savings?. http://www.which.co.uk/. Cited 21/06/2016

[32] Breazeale, Lloyd Caleb, and Rajapandian Ayyanar. "A photovoltaic array transformer-less inverter with film capacitors and silicon carbide transistors."IEEE Transactions on Power Electronics, Vol.30, No.3, pp.1297-1305, 2015

[33] Khan, Md Noman Habib, et al. "Evaluation of Various Leakage Current Paths with Different Switching Conditions." International Conference on Computer and Communication Engineering (ICCCE), pp. $269-272,2014$

[34] Khan, Md Noman Habib, et al. "A Double PWM Source Inverter Technique with Reduced Leakage Current for Application on Standalone Systems."World Academy of Science, Engineering and Technology, International Journal of Electrical, Computer, Energetic, Electronic and Communication Engineering, Vol. 9, No. 2, pp.246251,2015

[35] Khan, M. N. H., et al. "Battery-Equivalent DC Supply from Leakage Current: PV to Transformer-less Inverter Topology." Indonesian Journal of Electrical Engineering and Informatics (IJEEI), Vol.4, No.2, 2016. 
[36] Khan, M. N. H., et al. "Photovoltaic (PV) Panel to Transformer-Less Inverter Topology: A Review Paper." Elixir International Journal, vol. 93, pp.39574-39581, 2016

[37] Khan, M. N. H., et al. "Effect of Leakage Current in the PV Transformer-Less Inverter Topology." International Journal of Engineering Science, Vol 6, No. 4, pp.3272-3275, 2016.

[38] Liu, Bangyin, et al. "Transformer-less grid-connected inverter with low leakage currents for photovoltaic generation system." 2015 IEEE Energy Conversion Congress and Exposition (ECCE), 2015.

[39] T. K. S. Freddy, N. A. Rahim, H. Wooi-Ping, and C. Hang Seng, "Comparison and Analysis of Single-Phase Transformerless GridConnected PV Inverters," IEEE Transactions on Power Electronics,vol. 29, no. 10, pp. 5358-5369, 2014.

[40] Kerekes, T. ; Koutroulis, E. ; Séra, D. ; Teodorescu, R. ; Katsanevakis, M., “An Optimization Method for Designing Large PV
Plants", IEEE Journal of Photovoltaics, vol. 3, no. 2, pp. $814-822$ April 2013.

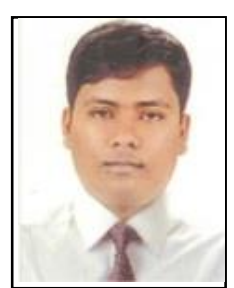

Md. Noman Habib Khan received the B.Sc degree in Electrical and Electronic Engineering (EEE) from Ahsanullah University Science and Technology (AUST), Bangladesh in 2009. However, he already finished his M.Sc degree from International Islamic University Malaysia (IIUM) Malaysia at 2014 and had been doing work as a research assistant at UMPEDAC department at University of Malaya (UM) with renewable energy especially solar, hydro, wind and hybrid for electrification issue. Now at present, he is doing work as a Lecturer in the Department of Electrical and Electronic Engineering (EEE), Uttara University (UU), Dhaka, Bangladesh. 